\title{
A Case of Glomangiopericytoma in the Prevertebral Space
}

\author{
Ho Jin Son, Yong Han Kim, and Soon Yuhl Nam \\ Department of Otolaryngology, Asan Medical Center, University of Ulsan College of Medicine, Seoul, Korea
}

\section{척추전공간에 발생한 사구맥관혈관주위세포종 1 예}

손호진 · 김용한 · 남순열

울산대학교 의과대학 서울아산병원 이비인후과학교실

\author{
Received November 18, 2016 \\ Revised December 27, 2016 \\ Accepted January 6, 2017 \\ Address for correspondence \\ Soon Yuhl Nam, MD, PhD \\ Department of Otolaryngology, \\ Asan Medical Center, \\ University of Ulsan \\ College of Medicine, \\ 88 Olympic-ro 43-gil, Songpa-gu, \\ Seoul 05505, Korea \\ Tel +82-2-3010-3966 \\ Fax +82-2-489-2773 \\ E-mailssynam@amc.seoul.kr
}

Glomanigiopericytoma is a rare vascular neoplasm with a perivascular myoid phenotype. It is rarely found in the neck but most commonly in the nose and paranasal sinuses. We experienced a case of 72-year-old man who presented a 5-year history of a right neck mass. The pathologic diagnosis was glomangiopericytoma. We removed the mass transcervically and the patient showed no postoperative problem. We report this case with a review of literature. Korean J Otorhinolaryngol-Head Neck Surg 2017;60(11):584-6

Key Words Glomangiopericytoma - Prevertebral space.

\section{서 론}

사구맥관혈관주위세포종(glomangiopericytoma)은 비강 및 부비동에서 주로 발생하며 종양 주위 혈관 성장이 분명한 특징을 가지며, 전체 비부비동 종양의 $0.5 \%$ 를 차지하는 드문 종양이다. ${ }^{1)}$

경부에 발생한 사구맥관혈관주위세포종은 국외에서 후두 및 후인두에서 발생한 1 예가 보고되었고, 국내에서는 아직까 지 경부에 발생한 보고는 없었다. 저자들은 최근 척추전공간 에 발병한 종물을 수술한 뒤 사구맥관주위혈관세포종으로 확진된 흔하지 않는 증례를 경험하였기에 문헌고찰과 함께 보고하고자 한다.

This is an Open Access article distributed under the terms of the Creative Commons Attribution Non-Commercial License (http://creativecommons.org/licenses/by-nc/4.0) which permits unrestricted non-commercial use, distribution, and reproduction in any medium, provided the original work is properly cited.

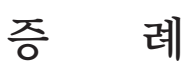

72세 남자 환자가 5년 전부터 발생한 우측 경부 종물을 주 소로 본원 이비인후과 외래에 내원하였다. 종물 이외에 호흡 곤란, 연하곤란, 인후통, 연하통, 목소리 변화, 흡인 등의 증 상은 없었다. 신체 검진에서 $5 \times 4 \mathrm{~cm}$ 크기의 가동성이 없고 단 단하며 무통성의 종물이 관찰되었으며, 후두경 검사에서 우 측 인두가 팽윤된 소견을 보였다(Fig. 1). 과거력에서 다른 질 환은 없었다. 2010년 타원에서 시행한 조영증강 단층촬영영 상에서 우측 척추전공간에 비균질적으로 조영증강되는 $4 \mathrm{~cm}$ 의 종물이 보였고 $\mathrm{C} 3, \mathrm{C} 5$ 신경근이 두꺼워져 있어 신경성종 양이 의심되었다. 세침 흡인 세포 검사에서 양성 염증성 낭종 (benign inflammatory cyst)으로 진단받았고, 2016년 본원에 서 시행한 조영증강 자기공명에서 종물이 $4.5 \mathrm{~cm}$ 크기로 증가 하였고, 경동맥을 전측방으로 전위시키면서, 우측 경장근(longus colli muscle)을 압박하였고, 경부신경고리(cervical nerve 
roots)와는 직접적인 연관관계를 보이지 않았으며 신경성종양 (neurogenic tumor) 또는 혈관과다종양(hypervascular tumor) 을 의심할 수 있었다. 또한 우측 3,5 번 경부신경고리에서 조 영증강되는 결절성 병변을 보였으며, 우측 2 3번과 4 5번 신 경공(neural foramen)이 넓어져 있었으며, 우측 5번 척추 횡 돌기(transverse process)가 압력으로 인한 미란 소견이 보였고 신경성종양을 의심할 수 있었다. 경부 림프절비대 소견은 보 이지 않았다(Fig. 2).

경부 초음파 도플러에서 혈류가 많지 않아 초음파 유도하 에 중심바늘생검(core needle biopsy)을 시행하였고 근육성 분 화(myogenic differentiation)를 보이는 저등급 상피모양 중간 엽 종양(low grade epithelioid mesenchymal neoplasm) 소

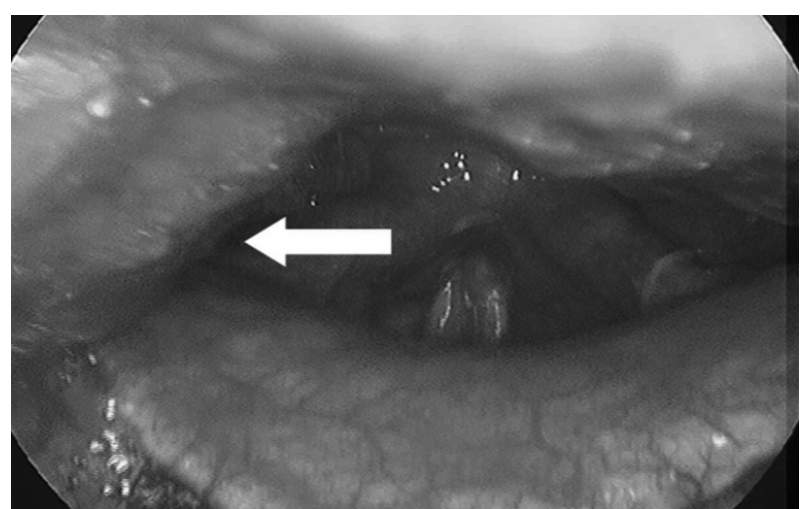

Fig. 1. Preoperative laryngoscopy finding. Rt pharyngeal bulging is found (white arrow).
견을 보였으며, 사구맥관혈관주위세포종(glomangiopericytoma), 사구종양(glomus tumor), 부신경종(paraganglioma), 신경성종양(neurogenic tumor)의 가능성이 있었다.

환자는 전신마취하에 하악골 $2 \mathrm{~cm}$ 하방에서 경부접근법으 로 수평절개를 하였고, 종물은 흥쇄유돌근(sternocleiodmastoid muscle), 내경정맥, 경동맥을 외측으로 전이시키고 있었 고, 경장근과 두장근(longus capitis)과 접해 있었다. 경부 신 경초를 따라 종물을 피막박리 하였고, 우측 2 3번, 4 5번 신 경공과 종물 사이의 경부 신경초를 통한 연결을 절단한 후 종 물을 제거하였다. 종물은 주변근육, 경동맥, 내경정맥과 접하 여 있었으나 피막박리로 비교적 박리가 잘되었으며, 자기공명 영상에서 과다혈관 종양이 의심되었으나 술 중 출혈은 거의 없었고, 동결절편 검사는 시행하지 않았다. 종물 절제 후 미 주신경과 인두부위는 이상이 없었고 배액관을 유치한 후 수 술을 종료하였다. 수술 후 환자는 호흡곤란, 삼킨곤란, 호너 증후군, 상지 위약감이나 감각이상 및 성대마비 증상은 보이 지 않았고 2일 후 퇴원하였다.

종물은 $5 \times 4.4 \times 2.0 \mathrm{~cm}$ 크기의 사구맥관혈관주위세포종이 었으며 uncertain malignant potential을 보였다. 현미경 소견 에서 림프혈관 및 신경주위 침범(lymphovascular and perineural invasion)은 보이지 않았으며, high-power field에서 10 개 중 3 개에서 유사분열(mitosis) 소견을 보였고, 면역조직 화학염색에서 smooth muscle actin(SMA)에 양성 및 CD31, CD34에 음성을 보였다(Fig. 3).

Fig. 2. Preoperative MRI \& CT scan. Enhanced magnetic resonance image axial $(A)$ scan shows a heterogenously enhancing lobulated mass in the right prevertebral space, displacing carotid artery anterolaterally (small arrow) \& widening C4-5 neural foramen with pressure erosion in the right $\mathrm{C} 5$ transverse process (large arrow). Enhanced computed tomography coronal (B) scan shows C3 nerve root thickening (arrow).
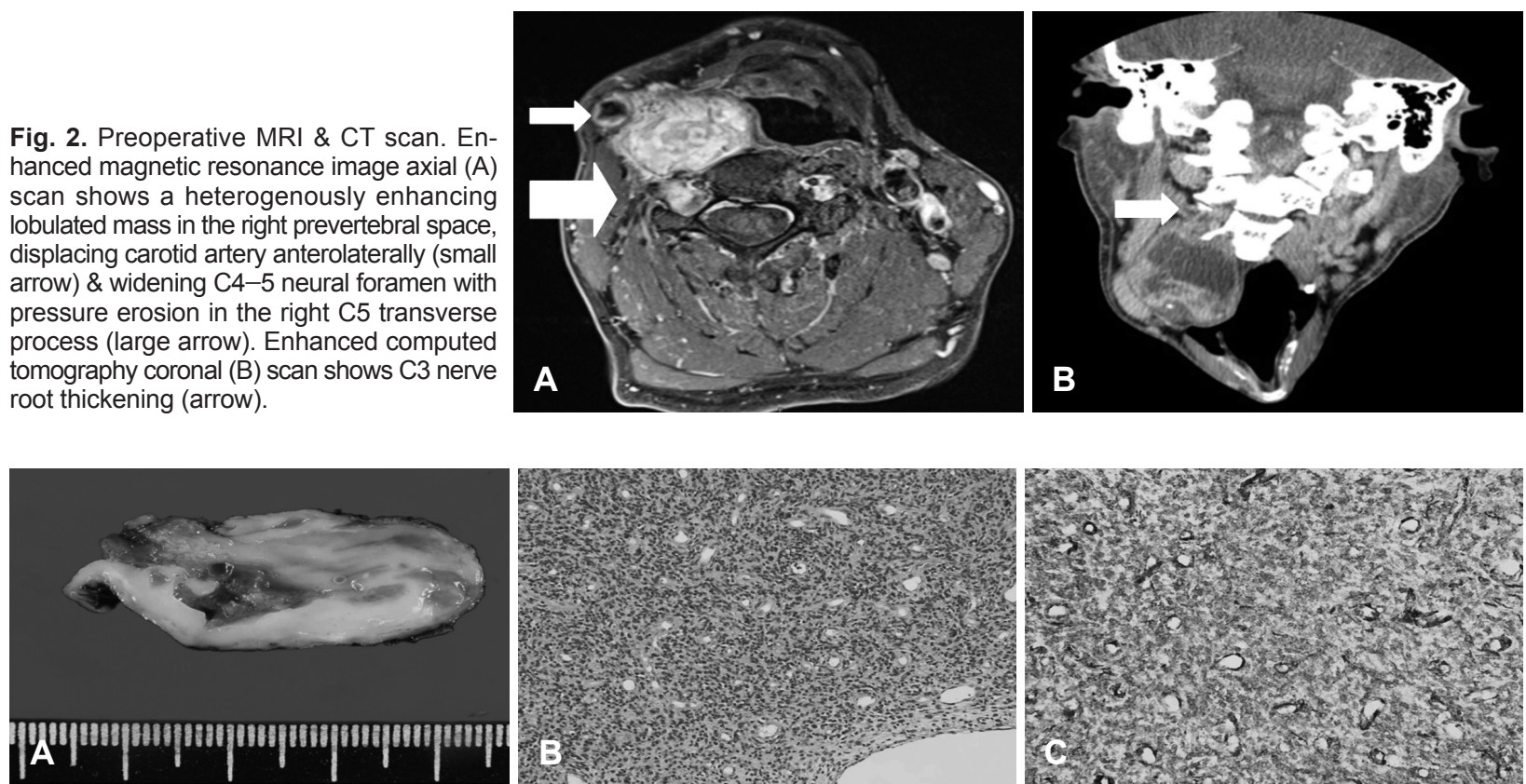

Fig. 3. Postoperative surgical specimen finding. $5 \times 4.4 \times 2 \mathrm{~cm}$ mass is yellowish white, soft, and focally hemorrhagic (A). Histopathologic finding. The spindle cell proliferation has a fascicular growth arrangement around the vascular stroma $(H \& E, \times 200)(B)$. Strong reactivity of tumorous cells for smooth muscle actin (smooth muscle actin stain, $\times 200)(C)$. 
환자는 현재 추가적인 치료 없이 이비인후과 외래에서 6개 월째 경과관찰 중이며, 재발의 소견을 보이지 않고 있다.

\section{고 찰}

사구맥관주위혈관세포종은 근육주위세포종(myopericytoma)에 속하며, 이는 혈관주위세포종 유사종양(hemangiopericytoma-like tumor)에 속한다. ${ }^{1)}$ 이전 보고에서, 사구맥 관주위혈관세포종은 조직학적으로 원형 또는 방추형 세포 (round to spindle cell)에 사슴뿔모양으로 분지되는 혈관이 분포되어(staghorn vascular pattern) 혈관주위세포종으로 보고되었으나.2) 이러한 정의에 많은 의문점이 있었다.,4) 최 근 SMA에 양성을 보이는 방추형 세포가 근육양분화(myoid differentiation) 하는 것을 발견하여 혈관주위세포종의 개념 은 근육주위세포종으로 변화하고 있다. ${ }^{5)}$ 사구맥관주위혈관 세포종은 사구종양(glomus tumor)과 마찬가지로 근육양분 화를 하여 면역조직화학염색에서 유사한 양상을 보이나,)사 사 구맥관혈관주위세포종은 세포핵에 베타카테닌(B-catenin) 이 축적되어 이를 통하여 감별할 수 있다. ${ }^{7)}$

사구맥관혈관주위세포종은 여성에서 발병률이 높으며, 평 균발병시기는 60 70세라고 알려져 있다. ${ }^{1)}$ 발병원인은 아직 알 려져 있지 않으나, 과거 외상, 고혈압, 임신 그리고 스테로이드 복용력 등이 유발원인으로 고려되고 있다. ${ }^{8)}$

현재까지 100예 이상의 혈관주위세포종 유사종양이 보고되 었으나호도든 증례가 비강이나 부비동을 침범하여 부비강 혈 관주위종양으로 명명되었다. 그러므로 증상은 비출혈이 가장 많았으며, 코막힘, 통증, 호흡곤란 등이 나타났었다. ${ }^{10)}$

조직학적으로 glomus-like round cell이 풍부하며, $\mathrm{H \& E}$ stain에서 많은 혈관통로와 혈관주위로 동심성 세포성장을 볼 수 있으며 glomus like round cell은 혈관을 따라 배열되어 있 다. 면역조직화학염색에서 vimentin, SMA에 강양성을 보이며, $\mathrm{CD} 31, \mathrm{CD} 34$ 에 음성을 보이며, 일부 세포는 factor VIII에 양 성을 보인다. ${ }^{11}$

경부에 발생한 사구맥관혈관주위세포종은 2016년 Fox 등리 에 의해 처음 보고되었으며 우측 후인두와 후두를 침범하는 종물이었다. 혈관조영술을 하여 종물이 상갑상동맥에 혈액 공급을 받는 것을 확인한 후 색전술을 시행하였고, 경부접근 법으로 종물을 제거하였다. 종물은 SMA, desmin에 양성이었 으며 CD34, pancytokeratin, S100, CD99에 음성을 보였고 사 구맥관혈관주위세포종으로 확진되었다.

사구맥관혈관주위세포종의 치료는 완전한 수술적 절제이
다. ${ }^{13)}$ 종물은 혈관이 매우 풍부하기 때문에 술 전 색전술을 권 하는 경우도 있다. ${ }^{14)}$ 사구맥관혈관주위세포종은 WHO 분류 에 의해 경계선 저악성도 종양으로 분류되기 때문에 소수에 서 재발할 수 있으며, 치명적일 수가 있으므로, 재발을 막기 위 해서 불완전한 수술적 절제는 피해야 한다. ${ }^{3}$ 또한 불완전 절 제가 되었거나 절제연이 침범되었을 때 술 후 방사선 치료가 도움이 될 수 있다. ${ }^{15)}$ 사구맥관혈관주위세포종은 매우 드물고 부비강에서 주로 발생한다고 알려져 경부에 발생한 보고는 거의 없다. 그러므로 본 증례와 더불어 더 많은 증례 보고들 이 모여 치료 및 예후에 대한 공유가 필요하리라 생각된다.

\section{REFERENCES}

1) Thompson LD, Fanburg-Smith JC. Update on select benign mesenchymal and meningothelial sinonasal tract lesions. Head Neck Pathol 2016;10(1):95-108.

2) Stout AP, Murray MR. Hemangiopericytoma: a vascular tumor featuring Zimmermann's pericytes. Ann Surg 1942;116(1):26-33.

3) Thompson LD, Miettinen M, Wenig BM. Sinonasal-type hemangiopericytoma: a clinicopathologic and immunophenotypic analysis of 104 cases showing perivascular myoid differentiation. Am J Surg Pathol 2003;27(6):737-49.

4) Gengler C, Guillou L. Solitary fibrous tumour and haemangiopericytoma: evolution of a concept. Histopathology 2006;48(1):63-74.

5) Granter SR, Badizadegan K, Fletcher CD. Myofibromatosis in adults, glomangiopericytoma, and myopericytoma: a spectrum of tumors showing perivascular myoid differentiation. Am J Surg Pathol 1998; 22(5):513-25.

6) Tse LL, Chan JK. Sinonasal haemangiopericytoma-like tumour: a sinonasal glomus tumour or a haemangiopericytoma? Histopathology 2002;40(6):510-7.

7) Lasota J, Felisiak-Golabek A, Aly FZ, Wang ZF, Thompson LD, Miettinen M. Nuclear expression and gain-of-function $\beta$-catenin mutation in glomangiopericytoma (sinonasal-type hemangiopericytoma): insight into pathogenesis and a diagnostic marker. Mod Pathol 2015; 28(5):715-20.

8) Angouridakis N, Zaraboukas T, Vital J, Vital V. Sinonasal hemangiopericytoma of the middle turbinate: a case report and brief review of the literature. B-ENT 2007;3(3):139-43.

9) Marianowski R, Wassef M, Herman P, Huy PT. Nasal haemangiopericytoma: report of two cases with literature review. J Laryngol Otol 1999;113(3):199-206.

10) Watanabe K, Saito A, Suzuki M, Yamanobe S, Suzuki T. True hemangiopericytoma of the nasal cavity. Arch Pathol Lab Med 2001;125(5):686-90.

11) Sun Q, Zhang C, Chen W, He Y. The molecular mechanisms on glomangiopericytoma invasion. Orphanet J Rare Dis 2013;8:152.

12) Fox DP, Helekar BS, Gallagher KK. Laryngeal, retropharyngeal, and cervical glomangiopericytomas: a case report. Otolaryngol Head Neck Surg 2016;155(6):1059-60.

13) Thompson LD. Sinonasal tract glomangiopericytoma (hemangiopericytoma). Ear Nose Throat J 2004;83(12):807.

14) Palacios E, Restrepo S, Mastrogiovanni L, Lorusso GD, Rojas R. Sinonasal hemangiopericytomas: clinicopathologic and imaging findings. Ear Nose Throat J 2005;84(2):99-102.

15) Carew JF, Singh B, Kraus DH. Hemangiopericytoma of the head and neck. Laryngoscope 1999;109(9):1409-11. 